\title{
Consumption and Characterization of Forestry Biomass Used in Tobacco Cure Process
}

\author{
Carline Andréa Welter ${ }^{1}$ (D), Jorge Antonio de Farias $^{1}$ (D), \\ Dimas Agostinho da Silva² (D), Rafael da Silva Rech ${ }^{1}$ (D), \\ Débora da Silva Teixeira ${ }^{1}$ (D), Cristiane Pedrazzi ${ }^{1}$ (i) \\ ${ }^{1}$ Universidade Federal de Santa Maria - UFSM, Santa Maria/RS, Brasil \\ ${ }^{2}$ Universidade Federal do Paraná - UFPR, Curitiba/PR, Brasil
}

\begin{abstract}
The tobacco production requires annually a large volume of firewood used in the cure process of tobacco leaves, representing up to $10 \%$ of its production cost. An alternative is the use of agroindustry residues, such as sawdust or pellets. The objective of this study was to analyze the consumption and to characterize forestry biomass used in the tobacco cure process in farmers from Candelária, Southern Brazil, aiming the culture energetic efficiency. Forestry biomass consumption, residues formation after combustion and biomass quality were verified. In terms of available energy, the consumption for each kilogram of dry tobacco was $77.23 \mathrm{MJ}$ for firewood, $61.40 \mathrm{MJ}$ for sawdust and $37.51 \mathrm{MJ}$ for pellets. Pellets presented the best physicochemical characteristics for use as energy, as well as the lowest consumption and the lowest organic fraction present in combustion residues.
\end{abstract}

Keywords: bioenergy, tobacco production, energetic efficiency. 


\section{INTRODUCTION}

In southern Brazil, tobacco farming is an activity of great economic importance, and requires annually a large volume of forest biomass (firewood), used in the curing process of tobacco leaves, corresponding to about $10 \%$ of the production cost of the "Virginia" variety (Farias et al., 2017). The three states in southern Brazil consume approximately 1.8 million tons of firewood per crop to cure the produced tobacco (Schoenhals et al., 2009).

The search for alternatives to the firewood consumption, or its reduction, has shown to be promising. Some of the alternatives include the use of sawdust in tobacco curing units, which is a recent technology, making it possible to use a low-cost and easy handling residue. However, the high variability of biomass residues ends up by decreasing the useful calorific value when applied in the fresh form. An economical and technically more interesting option for the use of biomass would be its use as raw material for new products of higher added value such as pellets, which has the advantage of being homogeneous with superior properties for combustion purposes.

Brazil has great potential to produce energy from biomass, which goes beyond those used by industries. In addition to firewood, other sources of biomass have been studied to find alternatives for energy generation. As an example, Sater et al. (2011) evaluated the energy potential of residues generated in coffee processing and wood milling for the drying of coffee beans, and Quéno et al. (2011) concluded that elephant grass biomass can present competitive energy production costs, depending on production conditions.

In relation to other types of renewable energies, biomass, being chemical energy, stands out for the high energy density and easy storage, conversion and transportation (Saad et al., 2010).

The objective of this work was to analyze the consumption and characterization of forestry biomass used in the tobacco cure process, aiming to increase the energy efficiency of this agricultural crop.

\section{MATERIAL AND METHODS}

The research was carried out in two tobacco farms, for a period of three years during the tobacco crop. Both have metallic curing units, with forced air technology, and tobacco leaves are accommodated in staples. In this system, the hot air generated in the combustion chamber circulates through the curing structure being driven by a fan that sucks and directs hot air through tobacco leaves and returns to the heating zone by pressure difference.

The curing units contain electronic controllers, which maintain the temperature set in the curing program selected by the producer, indicating the need to manually add firewood or sawdust and pellets in an automated process.

The forestry biomasses used were:

a) Firewood: all wood used was from Eucalyptus spp., acquired in the city of Candelária, RS, Brazil;

b) Sawdust: obtained from sawmills of Candelária, RS, Brazil, whose absolute predominance of the forest raw material was from the genus Eucalyptus; and

c) Pellets: obtained from company Chamape Energias Sustentáveis Ltda., located in Vale Real, RS, Brazil, whose forest raw material was from the genus Pinus.

For biomass characterization, 6 samples were randomly collected for each biomass, being identified and sent to the UFSM Laboratory of Wood Chemistry for analysis of moisture content, basic wood density, lignin content, immediate chemical analysis and heating value. The energy density was also calculated.

To verify the consumption and technical efficiency of each used biomass, 3 cure repetitions were performed (tobacco batches, process lasting around 6 days), when the quantity of staples inside the chamber, the average weight of three staples, before and after cure, the volume and weight of biomass used $\left(\mathrm{m}^{3}\right.$ and $\mathrm{kg}$ ) were verified. In addition, all residues resulting from combustion (ashes) were weighed and samples were collected for the organic fraction quantification (fixed carbon and volatile materials).

Biomass volume determination, in the case of firewood, was carried out by Smalian's rigorous cubing method; for sawdust and pellets, a known volume vessel was used to supply the furnace feeder.

Data were processed with the aid of Microsoft Excel $^{\circledR}$. Consumption averages and physicochemical characteristics were compared by the Tukey's test at $5 \%$ probability. 


\section{RESULTS AND DISCUSSION}

Pellets presented the best characteristics for energy production, highlighting the higher heating value, lignin content and highest energy density. The average results of biomass quality parameters are presented in Table 1.

The higher lignin content in pellets is associated with the species of origin, since conifers present higher percentages of this structural component in their wood. Additionally, the higher heating value in more lignified woods is due to the higher percentage of elemental carbon (65\%) in its composition, when compared to holocellulose (45\%) (Pereira et al., 2000).

Firewood has the most complex form of combustion among the three solid fuels under analysis due to the lower contact surface for burning and high humidity, thus reducing its combustion power due to the energy required for boiling capillary water during the combustion process.

Moreover, there is a greater difficulty in the loss of moisture present in logs in relation to the other biomasses because the rate with which water moves from a material to the atmosphere is inversely proportional to its thickness (Park et al., 2014). In addition, species of the genus Eucalyptus naturally present relative impermeability due to their anatomical characteristics, making the capillary water loss process even more difficult (Batista et al., 2015).

Although with high moisture content, sawdust exhibited higher combustion, since in the form of particles, it presents greater contact surface, facilitating the burning process, homogeneously. Due to its uniform composition, pellet has low moisture content and high density, presenting the best results in relation to the combustion efficiency.
Firewood has higher consumption in comparison to pellets due to its higher moisture content and lower specific surface area (Table 2).

The average energy consumption $(\mathrm{kcal} / \mathrm{kg}$ dry tobacco) in the pellet system was $51.4 \%$ more efficient compared to firewood and $38.9 \%$, compared to sawdust due to product density and moisture content of pellet, less than $10 \%$.

Siddiqui \& Rajabu (1996), in Tanzania, using traditional barns, verified that for each $\mathrm{kg}$ of cured tobacco, there is a consumption of $14 \mathrm{~kg}$ of dry wood. Wang et al. (2015), in China, verified that $1 \mathrm{~kg}$ of dry tobacco required at least $3 \mathrm{~kg}$ of biomass as fuel, tested in three fire furnaces with different heat exchangers, using tobacco stems briquette (TSB) and honeycomb briquette (HB), comparatively.

In Table 3, the average amount of combustion residues in each batch and the presence of organic material (fuel) in this fraction can be verified. Regarding the representativeness of the total consumed biomass, it was verified that with the use of firewood, there was greater production of residues, $1.2 \%$ of all the wood that entered the process was not consumed and stored as ashes. For sawdust and pellets, this percentage was $0.44 \%$ and $0.15 \%$, respectively, possibly due to the different combustion reactions inside the furnace, which are even more complex due to the larger contact area of firewood.

Chemical analyses indicated the presence of residual organic fraction after combustion in ashes. The combustion residue of pellets was the one that presented smaller fixed carbon contents, indicating higher material combustion and, thus, smaller losses of combustible material. Sawdust presented intermediate results in relation to carbon, but higher percentage of volatile materials. In firewood combustion, the presence

Table 1. Average quality parameters of forestry biomass used as thermal energy source in the curing process of tobacco leaves.

\begin{tabular}{|c|c|c|c|c|c|c|c|c|c|}
\hline Biomass & $\begin{array}{c}\text { HHV } \\
\left({\left.\mathrm{kcal} . \mathrm{kg}^{-1}\right)}^{-}\right)\end{array}$ & $\begin{array}{c}\text { LHV } \\
\left(\mathrm{kcal}^{\left.-k^{-1}\right)}\right)\end{array}$ & $\begin{array}{l}\text { VM } \\
(\%)\end{array}$ & $\begin{array}{l}\text { FC } \\
(\%)\end{array}$ & $\begin{array}{l}\mathrm{AC} \\
(\%)\end{array}$ & $\begin{array}{l}\text { LC } \\
(\%)\end{array}$ & $\begin{array}{l}\text { MC } \\
(\%)\end{array}$ & $\begin{array}{c}\text { WBD } \\
\left(\mathrm{g} \cdot \mathrm{cm}^{-3}\right)\end{array}$ & $\begin{array}{c}\text { ED } \\
\left(\text { Gcal.m}^{-3}\right)\end{array}$ \\
\hline Firewood & $4662 b^{*}$ & $4310 \mathrm{~b}$ & $82.8 \mathrm{a}$ & $17.0 \mathrm{c}$ & $0.23 \mathrm{~B}$ & $20.9 \mathrm{~b}$ & $35.0 \mathrm{a}$ & $0.49 \mathrm{a}$ & 2.1 \\
\hline Sawdust & $4647 b$ & $4301 \mathrm{~b}$ & $76.0 \mathrm{c}$ & $23.1 \mathrm{a}$ & $0.92 \mathrm{Ab}$ & $24.6 \mathrm{ab}$ & $31.1 \mathrm{a}$ & $0.30 \mathrm{~b}$ & 1.3 \\
\hline Pellets & $4801 \mathrm{a}$ & 4457 a & $79.3 \mathrm{~b}$ & $19.4 \mathrm{~b}$ & $1.31 \mathrm{~A}$ & $29.0 \mathrm{a}$ & $9.5 \mathrm{~b}$ & $0.52 \mathrm{a}$ & 2.3 \\
\hline
\end{tabular}

${ }^{*}$ Means followed by different vertical letters differ by the Tukey test at $5 \%$ probability. HHV $=$ High heating value; LHV $=$ Low heating value; $\mathrm{VM}=$ Volatile material content $\mathrm{FC}=$ Fixed carbon content; $\mathrm{AC}=$ Ash content $\mathrm{LC}=$ lignin content $\mathrm{MC}=\mathrm{Moisture}$ content on dry basis; WBD = Basic specific mass; $\mathrm{ED}=$ Energy density. 
Table 2. Average forest biomass consumption (in $\mathrm{kg}$ and kcal) for each kilogram of dry tobacco.

\begin{tabular}{lcr}
\multicolumn{1}{c}{ Biomass } & \multicolumn{1}{c}{ Kg } & kcal \\
Firewood & $4.28 \pm 1.53 \mathrm{a}^{*}$ & 18.447 \\
Sawdust & $3.41 \pm 0.97 \mathrm{a}$ & 14.666 \\
Pellets & $2.01 \pm 0.52 \mathrm{~b}$ & 8.959 \\
\hline
\end{tabular}

${ }^{*}$ Means followed by different vertical letters differ by the Tukey test at $5 \%$ error probability.

Table 3. Average amount and immediate chemical analysis of combustion residues from the biomass per tobacco batch.

\begin{tabular}{lcrrr} 
& \multirow{2}{*}{$\begin{array}{c}\text { Combustion } \\
\text { Besidues }\end{array}$} & \multicolumn{3}{c|}{$\begin{array}{c}\text { Immediate Chemical } \\
\text { Analysis }\end{array}$} \\
\cline { 3 - 6 } & (kg/batch) & VM (\%) & FC (\%) & AC (\%) \\
\hline Firewood & $29.6 \pm 2.8 \mathrm{a}$ & $3.91 \mathrm{a}$ & $15.96 \mathrm{a}$ & $80.13 \mathrm{c}$ \\
\hline Sawdust & $6.0 \pm 1.8 \mathrm{~b}$ & $4.40 \mathrm{a}$ & $6.53 \mathrm{~b}$ & $89.06 \mathrm{~b}$ \\
\hline Pellets & $1.9 \pm 0.2 \mathrm{c}$ & $2.54 \mathrm{a}$ & $0.65 \mathrm{c}$ & $96.80 \mathrm{a}$ \\
\hline
\end{tabular}

${ }^{*}$ Means followed by different vertical letters differ by the Tukey test at $5 \%$ error probability. $\mathrm{VM}=$ Volatile material content; $\mathrm{FC}=$ Fixed carbon content; $\mathrm{AC}=$ Ash content .

of $16 \%$ of fixed carbon in the residual furnace was significant, indicating considerable loss of fuel that could be better used.

\section{CONCLUSION}

Pellets presented the best physicochemical characteristics for energy production, as well as the lowest consumption. Although presenting the lowest density, heating value and energy density, sawdust presented lower consumption compared to firewood, which may result from its greater contact surface, providing more efficient burning, but this difference was not statistically significant. Additionally, firewood presented the highest content of volatile materials and lower percentage of lignin, characterizing a faster burning material.

It should be noted that the results for sawdust and pellets could be even better, since the combustion chambers of curing units are, by default, dimensioned for the use of wood, damaging the stoichiometric ratio between air and fuel. Resizing furnaces, specific pellet burners or the use of fluidized bed for sawdust are some technological adaptations that could bring advantageous results for sustainability and energy efficiency of the tobacco sector.
Furthermore, the high moisture values for firewood and sawdust influence the higher biomass consumption and lower combustion efficiency, and cause problems in the structure of curing units. Better biomass management by producers, such as pre-drying, storage in covered area and/or increase in the storage time before combustion, could also result in better efficiency indices.

\section{ACKNOWLEDGEMENTS}

This work acknowledges the Japan Tobacco International and the National Council for the Improvement of Higher Education Personnel (CAPES) for the financial support.

\section{SUBMISSION STATUS}

Received: 18 nov., 2018

Accepted: 13 dec., 2018

\section{CORRESPONDENCE TO}

\section{Carline Andréa Welter}

Universidade Federal de Santa Maria - UFSM, Av. Roraima, 1000, CEP 97105-900, Santa Maria, RS, Brasil

e-mail: carlinewelter@gmail.com

\section{FINANCIAL SUPPORT}

Japan Tobacco International (Grant/Award Number: 23081.000845/2012-90); Coordenação de Aperfeiçoamento de Pessoal de Nível Superior (Grant/Award Number: 42002010015P6).

\section{REFERENCES}

Batista DC, Klitzke RJ, Rocha MP. Qualidade da secagem convencional conjunta da madeira de clones de três espécies de Eucalyptus sp. Ciência Florestal 2015; 25(3): 711-719. http://dx.doi.org/10.5902/1980509819621.

Farias JA, Schneider PR, Biali LJ. Diagnóstico das florestas plantadas na Bacia Hidrográfica do Rio Pardo - RS. Ciência Florestal 2017; 27(1): 339-352. http://dx.doi. org/10.5902/1980509826472.

Park KJB, Park KJ, Alonso LFT, Cornejo FEP, Dal Fabbro IM. Secagem: fundamentos e equações. Revista Brasileira 
de Produtos Agroindustriais 2014; 16(1): 93-127. http:// dx.doi.org/10.15871/1517-8595/rbpa.v16n1p93-127.

Pereira JCD, Sturion JÁ, Higa AR, Higa RCV, Shimizu JY. Características da madeira de algumas espécies de eucalipto plantadas no Brasil. Colombo: Embrapa Florestas; 2000. 113 p. (Documentos; no. 38).

Quéno LMR, Souza ÁN, Ângelo H, Vale AT, Martins IS. Custo de produção das biomassas de eucalipto e capimelefante para energia. Cerne 2011; 17(3): 417-426. http:// dx.doi.org/10.1590/S0104-77602011000300017.

Saad SA, Isa KM, Bahari R. Chemically modified sugarcane bagasse as a potentially low-cost biosorbent for dye removal. Desalination 2010; 264(1-2): 123-128. http:// dx.doi.org/10.1016/j.desal.2010.07.015.

Sater O, Souza ND, Oliveira EAG, Elias TF, Tavares R. Estudo comparativo da carbonização de resíduos agrícolas e florestais visando à substituição da lenha no processo de secagem de grãos de café. Revista Ceres 2011; 58(6): 717 722. http://dx.doi.org/10.1590/S0034-737X2011000600006.

Schoenhals M, Follador FAC, Silva C. Análise dos impactos da fumicultura sobre o meio ambiente, à saúde dos fumicultores e iniciativas de gestão ambiental na indústria do tabaco. Engenharia Ambiental 2009; 6(2): 16-37.

Siddiqui KM, Rajabu H. Energy efficiency in current tobacco-curing practice in Tanzania and its consequences. Energy 1996; 21(2): 141-145. http://dx.doi.org/10.1016/03605442(95)00090-9.

Wang XF, Xu GZ, Zhang BL, Jiao YZ, Lu HF, Li BM. Application of tobacco stems briquetting in tobacco flue-curing in rural area of China. International Journal of Agricultural and Biological Engineering 2015; 8(6): 84-88. http://dx.doi.org/10.3965/j.ijabe.20150806.1842. 